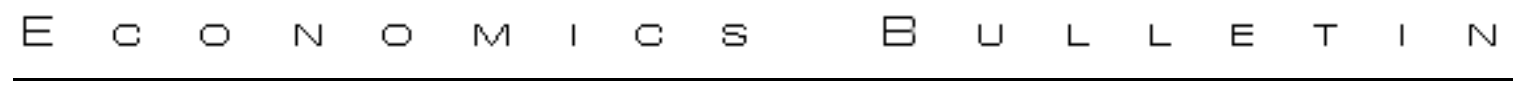

\title{
Forecasting aggregate stock returns using the number of initial public offerings as a predictor
}

\author{
Gueorgui I. Kolev \\ Department of Economics and Business, Universitat Pompeu Fabra
}

\begin{abstract}
Large number of Initial Public Offerings (IPOs) reliably predicts subsequent low equally weighted aggregate stock returns and the return differential between small and big firms, both in-sample and out-of-sample. The forecasting patterns are consistent with a behavioral story featuring investor sentiment and limits to arbitrage.
\end{abstract}

\footnotetext{
I would like to thank the anonymous referee for his competent and diligent referee report. His comments and suggestions substantially improved the quality of this paper. Remaining errors are mine.

Citation: Kolev, Gueorgui I., (2008) "Forecasting aggregate stock returns using the number of initial public offerings as a predictor." Economics Bulletin, Vol. 7, No. 13 pp. 1-8

Submitted: May 1, 2008. Accepted: October 14, 2008.

URL: http://economicsbulletin.vanderbilt.edu/2008/volume7/EB-08G10009A.pdf
} 


\section{Introduction}

The number of Initial Public Offerings (IPOs) reliably predicts subsequent aggregate stock returns both in-sample and out-of-sample at monthly frequency. Increases in the number of IPOs forecast significant decreases in the returns on equally weighted portfolio of all stocks in CRSP database. The effect for the value weighted market portfolio has the same sign, however it is statistically insignificant even in-sample. Increases in the number of IPOs forecast low returns among NASDAQ traded firms, however the effect is statistically significant both in and out-of-sample only when the index is constructed as equally weighted. The number of IPOs predicts remarkably well the return differential between small and big firms (Fama and French's $s m b$ ) judged by both in-sample and out-of-sample criteria.

The forecasting patterns are consistent with a behavioral story featuring investor sentiment and limits to arbitrage (Baker and Wurgler, 2007). Rational managers time the public equity market and take their firms public when investor sentiment is high and equity is overvalued. Subsequently as investor sentiment mean reverts or as arbitragers gradually bring values back to levels justified by fundamentals, the market experiences low aggregate returns. The effect is concentrated among firms that are more subject to sentiment or more difficult to arbitrage. Arguably small capitalization and high tech growth stocks are more difficult to value and arbitrage than large capitalization mature firms, and hence the former could be expected to be more affected by investor sentiment.

Investor sentiment seems a plausible explanation for the empirical patterns I document (Baker and Wurgler 2000, 2006, 2007). Yet some other fully rational mechanism might be at work. The fact that the number of IPOs predicts reliably insample and out-of-sample aggregate returns, where the effect is concentrated among small capitalization and high tech stocks, is of certain interest of its own right. This result comes in the midst of a recent large scale reexamination of the predictive ability of variables earlier proposed in the literature. This reexamination reaches conclusions ranging from the view that the evidence is somehow mixed (Rapach and Wohar, 2006) to the view that stock return predictability is not at all an empirical fact that one should rely upon (Goyal and Welch, 2007).

The result that one could predict future aggregate returns with the number of firms going public closely relates to Baker and Wurgler (2000). The latter paper shows that increases in the equity share in new issues, a variable very similar in spirit to the number of IPOs, predict subsequent decreases in aggregate stock returns. Although the two variables most likely reflect the same underlying phenomenon, they are sufficiently distinct both in terms of raw correlation $(=0.2787)$ and in terms of forecasting patterns they present. The finding that the number of IPOs predicts returns more pronouncedly among small capitalization and high tech stocks relates to Baker and Wurgler (2006). The authors construct an index of investor sentiment, part of which is also the contemporaneous number of IPOs, and show that in the cross section investor sentiment mostly affects valuations among stocks that are hard to value or hard to arbitrage.

The essay proceeds as follows. In Section 2 I outline the methodology that I use. In Section 3 I describe the data. In Section 4 I present the results. In Section 5 I show that the in-sample results are not an artifact of small-sample bias. In Section 6 I show that the number of IPOs predicts the small minus big return differential. In the last section I conclude. 


\section{Methodology}

Following much of the extant literature I estimate by Ordinary Least Squares bivariate predictive regressions where the gross real return on aggregate stock index is regressed on a constant and a lagged value of a predictor

$$
R_{t}=\beta_{0}+\beta_{1} X_{t-1}+u_{t}
$$

In different specifications $R$ is the gross real return on value and equally weighted portfolios of the universe of CRSP stocks and the value and equally weighted portfolios of stocks traded on the NASDAQ stock exchange. The predictor $X$ is the number of IPOs and for comparative purposes the equity share in new issues. $\beta$ s are population parameters to be estimated and $u$ is a disturbance term. The in-sample predictive ability of $X$ is assessed via the t-statistic corresponding to $b_{1}$, the OLS estimate of $\beta_{1}$ in eq. (1). Under the null hypothesis that $X_{t-1}$ does not help in predicting $R_{t}$ the expected returns are constant and $\beta_{1}=0$. Although the reasoning outlined in the Introduction suggests that $\beta_{1}$ should be less than 0 , I take the alternative hypothesis to be double sided, $\beta_{1} \neq 0$.

To generate out-of-sample predictions I use a recursive scheme. I split the sample into two halves with roughly equal number of observations. Let the total number of observations be $T$ and let the first half used for in-sample estimation contain $(T 1-1)$ observations. Let the second half used for out-of-sample predictions contain $(T 2+1)$ observations. Denote the null model prediction by $R_{p n, t}=b_{0, t-1}$ and the alternative model prediction by $R_{p a, t}=b_{0, t-1}+b_{1, t-1} X_{t-1}$. The mnemonics in the subscript $p n$ stand for "prediction with the null imposed", i.e., $b_{1}$ constrained to be 0 , and $p a$ for "prediction under the alternative," i.e. eq. (1). The $b$ s are estimated by OLS with data available only up to one period before the forecast is made, e.g., the first prediction under the alternative model eq. (1) is $R_{p a, T 1}=b_{0, T 1-1}+b_{1, T 1-1} X_{T 1-1}$ where the $b$ s are estimated using only data points from the 1 st though the $(T 1-1)$ th.

As an informal measure of out-of-sample performance of the predictive regression I report the out-of-sample R-squared of Campbell and Thompson (2006)

$$
\text { R-sqos }=1-\left\{\sum_{t=T 1, . ., \mathrm{T}}\left(R_{t}-R_{p a, t}\right)^{2}\right\} /\left\{\sum_{t=T 1, \ldots, \mathrm{T}}\left(R_{t}-R_{p n, t}\right)^{2}\right\} \text {. }
$$

To formally test the null hypothesis that eq. (1) does not improve upon the historical average return I employ the Clark and West (2007) Mean Squared Prediction Erroradjusted (MSPE-adj) statistic

$$
\text { MSPE-adj }=\Sigma_{t=T 1, . ., \mathrm{T}}\left\{\left(R_{t}-R_{p n, t}\right)^{2}-\left[\left(R_{t}-R_{p a, i}\right)^{2}-\left(R_{p n, t}-R_{p a, i}\right)^{2}\right]\right\} /(T 2+1) .
$$

Clark and West (2007) observe that under the null that $\beta_{l}=0$ the alternative model in eq. (1) estimates additional parameters whose population values are 0 and that the estimation induces additional noise. Hence under the null hypothesis the MSPE of the alternative model is expected to be larger than the MSPE of the null model. They propose an adjustment to the alternative model's MSPE. The term in square brackets in eq. (3) is the adjusted MSPE of the alternative model. Clark and West (2007) show that if the t-ratio associated with MSPE-adj exceeds the critical value of +1.282 then one can reject the null of no returns predictability in favor of the alternative model eq. (1), and 
that the size of the test is somewhere between 0.05 and 0.10 (i.e., the probability that we mistakenly reject a correct null is at most 0.10$)$.

\section{Data}

Monthly returns for equally and value weighted indices on all CRSP stocks are taken directly from CRSP. I construct monthly returns on equally and value weighted indices of stocks that are traded on the NASDAQ stock exchange. ${ }^{2}$ The monthly number of IPOs series covering January 1960 to December 2006 is downloaded from Jay Ritter's web page http://bear.cba.ufl.edu/ritter/. The series is an update of Ibbotson, Sindelar and Ritter (1994). The monthly share of equity in new issues is downloaded from Jeffrey Wurgler's web page http://pages.stern.nyu.edu/ jwurgler/. I use only the period which overlaps with the number of IPOs, from January 1960 to March 2006. Returns are converted to real terms using the CPI index downloaded from the web page of the Bureau of Labor Statistics.

Table 1, Summary statistics

nipo is the monthly number of IPOs, $s$ is the equity share in new issues. The rest of the variables are gross real monthly returns in percentage form, including dividends distributions: ewre is the equally weighted return on all CRSP stocks, vwre is the value weighted return on all CRSP stocks, nsdqewre is the equally weighted return on all stocks last observed trading on the NASDAQ stock exchange, and nsdqvwre is the value weighted return on all stocks last observed trading on the NASDAQ stock exchange.

\begin{tabular}{|llllll|}
\hline Variable & Obs & Mean & Std. Dev. & Min & Max \\
\hline nipo & 564 & 27.5 & 24.04455 & 0 & 122 \\
s & 555 & .1838175 & .1074827 & .0208771 & .6348659 \\
ewre & 563 & 100.889 & 5.600332 & 72.58585 & 129.4272 \\
vwre & 563 & 100.5982 & 4.390141 & 77.26484 & 115.418 \\
nsdqewre & 563 & 100.7537 & 6.407584 & 72.42509 & 129.5718 \\
nsdqvwre & 563 & 100.4484 & 6.288268 & 71.92438 & 122.7501 \\
\hline
\end{tabular}

The time series of monthly number of IPOs (nipo) appears to be stationary. The Dickey-Fuller test rejects the null that a unit root is present at any significance level. Visual inspection of the series does not reveal time trend, and the trend term is insignificant if included in any of the specifications. The augmented Dickey-Fuller test with 48 lags of the first differenced variable rejects the null that a unit root is present at the $5 \%$ significance level $(\mathrm{p}$-value $=0.0287)$.

\footnotetext{
${ }^{1}$ I implement the test as proposed in Section 2 of Clark and West (2007). I define the quantity in curly brackets in eq. (3) and regress it on a constant. The t-statistic from this regression is reported in Table 2.

${ }^{2}$ NASDAQ was opened in the beginning of the 70ies. The IPO data starts in year 1960. To avoid losing 10 years of data from this mismatch I include a stock in the index if the last exchange where the stock is observed trading is NASDAQ, i.e., I include stocks for which CRSP variable HEXCD=3.
} 


\section{Results}

Table 2, Returns predictions

The regressand being predicted is gross real monthly return in percentage form, including dividends distributions: ewre is the equally weighted return on all CRSP stocks, vwre is the value weighted return on all CRSP stocks, nsdqewre is the equally weighted return on all stocks last observed trading on the NASDAQ stock exchange, and nsdqvwre is the value weighted return on all stocks last observed trading on the NASDAQ stock exchange. The predictors are nipolag, one month lagged number of IPOs, or slag, one month lagged equity share in new issues. The statistics in the three columns labeled In-sample are computed using the full sample, January 1960 to December 2006. For the statistics in the columns labeled Out-of-sample, the sample is split into two roughly equal halves (containing respectively 281 and 283 observations when nipolag is the predictor) and recursive predictions are generated for the second half of the sample. The formulas for the computed statistics are given in Section 2.

\begin{tabular}{|c|c|c|c|c|c|c|c|}
\hline & \multicolumn{4}{|c|}{ In-sample } & \multicolumn{3}{|c|}{ Out-of-sample } \\
\hline regressand & predictor & $b_{1}$ & t-stat & $R-s q$ & $\begin{array}{l}\text { MSPE- } \\
\text { adj }\end{array}$ & $t$-stat & $R$-sqos \\
\hline ewre & $\begin{array}{l}\text { nipolag } \\
\text { slag }\end{array}$ & $\begin{array}{l}-.0327 \\
-6.6362 \\
\end{array}$ & $\begin{array}{l}-3.35 \\
-3.10 \\
\end{array}$ & $\begin{array}{l}0.0198 \\
0.0161\end{array}$ & $\begin{array}{l}1.3721 \\
.6388\end{array}$ & $\begin{array}{l}2.16 \\
1.28\end{array}$ & $\begin{array}{l}.0085 \\
-.0005\end{array}$ \\
\hline vwre & $\begin{array}{l}\text { nipolag } \\
\text { slag }\end{array}$ & $\begin{array}{l}-.0077 \\
-3.5794 \\
\end{array}$ & $\begin{array}{l}-0.92 \\
-2.11 \\
\end{array}$ & $\begin{array}{l}0.0018 \\
0.0076 \\
\end{array}$ & $\begin{array}{l}-.0486 \\
.3048 \\
\end{array}$ & $\begin{array}{l}-0.24 \\
1.31 \\
\end{array}$ & $\begin{array}{l}-.0111 \\
.0058 \\
\end{array}$ \\
\hline nsdqewre & $\begin{array}{l}\text { nipolag } \\
\text { slag }\end{array}$ & $\begin{array}{l}-.0413 \\
-8.9361\end{array}$ & $\begin{array}{l}-3.82 \\
-3.64 \\
\end{array}$ & $\begin{array}{l}0.0241 \\
0.0223\end{array}$ & $\begin{array}{l}2.1206 \\
1.2001\end{array}$ & $\begin{array}{l}2.37 \\
1.59 \\
\end{array}$ & $\begin{array}{l}.0069 \\
.0025\end{array}$ \\
\hline nsdqvwre & $\begin{array}{l}\text { nipolag } \\
\text { slag }\end{array}$ & $\begin{array}{l}-.0254 \\
-7.5581\end{array}$ & $\begin{array}{l}-2.36 \\
-3.13\end{array}$ & $\begin{array}{l}0.0095 \\
0.0165\end{array}$ & $\begin{array}{l}.6225 \\
1.1928 \\
\end{array}$ & $\begin{array}{l}0.86 \\
1.55\end{array}$ & $\begin{array}{l}-.0112 \\
.0075\end{array}$ \\
\hline
\end{tabular}

The results are contained in Table 2. Increases in the monthly number of IPOs and in the equity share in new issues predict decreases in the next month aggregate stock returns. Both predictors perform better (in terms of goodness of fit measures and strength of the rejection of the null of no predictability) when equally weighted returns are forecasted, where the effect is particularly pronounced for the number of IPOs. The marginal decrease in subsequent returns for a marginal increase in the number of IPOs and for a marginal increase in the equity share in new issues is also larger for equally weighted returns.

Both predictors reveal statistically significant in-sample predictive ability, except in the case when the number of IPOs is used to predict value weighted returns for all CRSP stocks. When prediction of equally weighted returns is the objective, the number of IPOs performs slightly better in-sample than the equity share in new issues.

The equity share in new issues forecasts well both equally and value weighted aggregate returns, regardless of whether performance is judged by in-sample or out-ofsample criteria.

The number of IPOs forecast reliably equally weighted aggregate returns both in-sample and out-of-sample. The t-statistic associated with the MSPE-adj is 2.16 and 2.37 for equally weighted, respectively all CRSP stocks and only NASDAQ stocks. It is well above the critical value of 1.282 and therefore the null hypothesis of no out-ofsample aggregate stock returns predictability is decisively rejected in favor of the one sided alternative that the number of IPOs is a superior predictor compared to the 
unconditional stock returns mean. The out-of-sample R-squared (labeled R-sqos) of 0.0085 and 0.0069 are remarkably high compared to the ones reported in other papers. ${ }^{3}$

\section{In-sample predictions: Is there small-sample bias?}

Regression coefficients and standard errors, obtained from predictive regressions employing a highly persistent predictor whose innovations are correlated with the innovations in the predictand, might exhibit severe small sample biases (Mankiw and Shapiro, 1986; Stambaugh, 1986,1999; Nelson and Kim, 1993). In this subsection I study whether the in-sample results in Table 2 are not an artifact of this small-sample bias.

The model is defined over the whole sample $t=1,2, \ldots, T$

$$
\begin{aligned}
& R_{t}=\beta_{0}+\beta_{1} X_{t-1}+u_{t} \\
& X_{t}=\mu+\rho X_{t-1}+w_{t}
\end{aligned}
$$

where the disturbances $\left(u_{t}, w_{t}\right)$ are serially independently and identically distributed as bivariate normal, and the autoregressive coefficient in eq. (5) is less than 1.

I follow the bias correction methodology of Amihud and Hurvich (2004). As a matter of notation, a superscript $c$ always denotes a bias corrected estimator in what follows.

First, I estimate eq. (5) to obtain the OLS estimator $r$ of $\rho$. From $r$, I compute the bias corrected estimator of $\rho$

$$
r^{c}=r+(1+3 r) / T+3(1+3 r) / T^{2} \text {. }
$$

The bias corrected estimator $r^{c}$ is used to compute corrected residuals $\hat{w}_{t}^{c}$ for eq. (5)

$$
\hat{w}_{t}^{c}=X_{t}-\left(m+r^{c} X_{t-1}\right)
$$

where $m$ is the OLS estimator of $\mu{ }^{4}$

Second, I run an auxiliary regression of $R_{t}$ on intercept, $X_{t-1}$ and $\hat{w}_{t}^{c}$. Denote by $b_{1}{ }^{c}$ the OLS estimator of the slope parameter on $X_{t-1}$ and by $f^{c}$ the OLS estimator of the slope parameter on $\hat{w}_{t}^{c}$ in this auxiliary regression. $b_{1}{ }^{c}$ is the bias corrected estimator of $\beta_{l}$ in which we are interested.

Finally, to conduct inference on $\beta_{l}$, we need the bias corrected standard error of $b_{1}^{c}$, which is given by the formula

$$
\left[\operatorname{SE}^{\mathrm{c}}\left(b_{1}{ }^{c}\right)\right]^{2}=\left[f^{c}\right]^{2} *\left[1+3 / T+9 / T^{2}\right]^{2} *[\operatorname{SE}(r)]^{2}+\left[\operatorname{SE}\left(b_{l}{ }^{c}\right)\right]^{2},
$$

where $\operatorname{SE}(r)$ denotes the usual OLS standard error of $r$ produced by any regression package and $\operatorname{SE}\left(b_{l}{ }^{c}\right)$ denotes the usual OLS standard error of $b_{1}{ }^{c}$, which comes as a direct output from the auxiliary regression of $R_{t}$ on intercept, $X_{t-1}$ and $\hat{w}_{t}^{c}$.

\footnotetext{
${ }^{3}$ Campbell and Thompson (2006) Table 1, column 5 and Goyal and Welch (2007) Table 3, column 4 report R-sqos. However the comparison is only suggestive, as their definition of returns is different and their sample period is different too.

${ }^{4}$ The choice of estimator $m$ is inconsequential for the bias in the predictive regression slope.
} 
Table 3: In-sample bias corrected statistics from the predictive regressions:

The regressands and the predictors are as in Table 2. $b_{l}{ }^{c}$ is the Amihud and Hurvich (2004) bias corrected estimator of $\beta_{1}$ in eq. (4) and $\mathrm{SE}^{\mathrm{c}}\left(b_{1}{ }^{c}\right)$ is its bias corrected standard error. $t^{c}$-stat $=b_{1}{ }^{c} /\left[\mathrm{SE}^{\mathrm{c}}\left(b_{1}{ }^{c}\right)\right] . r$ is the OLS estimate of the autoregressive parameter $\rho$ in eq. (5). $r^{c}$ is the bias corrected estimator of $\rho$. Finally, $f^{c}$ is unbiased estimator of $\left[\operatorname{Cov}\left(u_{t}, w_{t}\right)\right] /\left[\operatorname{Var} w_{t}\right]$ (Amihud and Hurvich, 2004, Lemma 1).

\begin{tabular}{|c|c|c|c|c|c|c|c|}
\hline & & \multicolumn{3}{|c|}{ In-sample bias corrected } & \multicolumn{3}{|c|}{ Auxiliary statistics } \\
\hline regressand & predictor & $b_{1}^{c}$ & $\operatorname{SE}^{\mathrm{c}}\left(b_{1}{ }^{c}\right)$ & $t^{c}$-stat & $r$ & $r^{c}$ & $f^{c}$ \\
\hline ewre & $\begin{array}{l}\text { nipolag } \\
\text { slag }\end{array}$ & $\begin{array}{l}-.0323 \\
-6.6777 \\
\end{array}$ & $\begin{array}{l}.0097 \\
2.2155\end{array}$ & $\begin{array}{l}-3.32 \\
-3.01 \\
\end{array}$ & $\begin{array}{l}.8588 \\
.7369 \\
\end{array}$ & $\begin{array}{l}.8652 \\
.7427 \\
\end{array}$ & $\begin{array}{l}.0498 \\
-1.6567\end{array}$ \\
\hline vwre & $\begin{array}{l}\text { nipolag } \\
\text { slag }\end{array}$ & $\begin{array}{l}-.0074 \\
-3.6040 \\
\end{array}$ & $\begin{array}{l}.0077 \\
1.7446 \\
\end{array}$ & $\begin{array}{l}-.9618 \\
-2.06 \\
\end{array}$ & $\begin{array}{l}.8588 \\
.7369 \\
\end{array}$ & $\begin{array}{l}.8652 \\
.7427 \\
\end{array}$ & $\begin{array}{l}.0472 \\
-2.1743 \\
\end{array}$ \\
\hline nsdqewre & $\begin{array}{l}\text { nipolag } \\
\text { slag }\end{array}$ & $\begin{array}{l}-.0409 \\
-8.9843\end{array}$ & $\begin{array}{l}.0111 \\
2.5264\end{array}$ & $\begin{array}{l}-3.68 \\
-3.55\end{array}$ & $\begin{array}{l}.8588 \\
.7369\end{array}$ & $\begin{array}{l}.8652 \\
.7427\end{array}$ & $\begin{array}{l}.0538 \\
-.1496\end{array}$ \\
\hline nsdqvwre & $\begin{array}{l}\text { nipolag } \\
\text { slag }\end{array}$ & $\begin{array}{l}-.0249 \\
-7.6106 \\
\end{array}$ & $\begin{array}{l}.0109 \\
2.4848\end{array}$ & $\begin{array}{l}-2.27 \\
-3.06 \\
\end{array}$ & $\begin{array}{l}.8588 \\
.7369 \\
\end{array}$ & $\begin{array}{l}.8652 \\
.7427\end{array}$ & $\begin{array}{l}.0760 \\
1.1295\end{array}$ \\
\hline
\end{tabular}

Comparison of Table 3 and the left panel of Table 2 (in-sample results) reveals that the corrections for the finite sample bias do not make difference. Hence finite sample bias is not a problem when the number of IPOs is used as a predictor of stock returns.

The results in this section are not surprising. Baker Taliaferro and Wurgler (2006) show that the small-sample bias has negligible consequences for managerial decision variables, e.g., for the equity share in new issues that is studied here as well. ${ }^{5}$ Therefore by now it is well known that the model in eq. (4) and (5) has very different stochastic properties depending on whether the predictor $X$ is a managerial decision variable(e.g., number of IPOs or equity share in new issues), or a valuation ratio(e.g., aggregate dividend to price ratio, or aggregate book to market ratio).

\section{Forecasting the small minus big return differential}

The number of IPOs forecasts well equally-weighted aggregate stock returns, but not value-weighted returns (Table 2). I suggest that this is because managers time the market, and take their firms public when investor sentiment is high---subsequently as sentiment mean reverts or arbitragers correct mispricing, firms which are difficult to arbitrage $^{6}$ or difficult to value(e.g., small firms) experience low returns. If this is the case, the number of IPOs must forecast the return differential between small and big firms even better than the return on the aggregate equally weighted portfolio. Big firms, which are easy to value and arbitrage, are present in equally weighted portfolio too (albeit their impact is downplayed by weighting) and if the sentiment/limits to arbitrage story is true, big firms make the forecasting job of the number of IPOs harder.

In this section I show that the number of IPOs forecasts the return on the small minus big $(\mathrm{smb})$ portfolio of Fama and French, ${ }^{7}$ and the forecasting performance is

\footnotetext{
${ }^{5}$ Baker Taliaferro and Wurgler (2006) use different statistical techniques to demonstrate this---bootstrap and simulations under worse scenarios.

${ }^{6}$ By "difficult to arbitrage" I mean that arbitrage is gradual, and cannot correct prices instantly.

${ }^{7}$ I downloaded $s m b$ from Kenneth French's web site

http://mba.tuck.dartmouth.edu/pages/faculty/ken.french/data_library.html. In terms of gross returns, the
} 
remarkably better than the forecasting performance on the equally-weighted aggregate returns. The $s m b$ is the return differential between three portfolios including only small firms and three portfolios including only big firms. Within each portfolio, firms' returns are value weighted.

Table 4: The regressand is $s m b$ the return differential between small and big firms. The rest of the table has the same structure as Table 2, except that bias corrected t-statistics are added in square brackets bellow the usual t-statistics.

\begin{tabular}{|c|c|c|c|c|c|c|c|}
\hline & \multicolumn{4}{|c|}{ In-sample } & \multicolumn{3}{|c|}{ Out-of-sample } \\
\hline regressand & predictor & $b_{1}$ & $\begin{array}{l}t \text {-stat } \\
{\left[\mathrm{t}^{\mathrm{c}} \text {-stat }\right]}\end{array}$ & $R-s q$ & $\begin{array}{l}\text { MSPE- } \\
\text { adj }\end{array}$ & $t$-stat & $R$-sqos \\
\hline$s m b$ & nipolag & & $\begin{array}{l}-5.16 \\
{[-4.71]}\end{array}$ & 0.0387 & .9161 & 3.81 & .0379 \\
\hline & slag & -2.9944 & $\begin{array}{l}-2.71 \\
{[-2.42]}\end{array}$ & 0.0103 & -.0112 & -0.09 & -.0143 \\
\hline
\end{tabular}

Table 4 reveals remarkable ability of the number of IPOs to predict the small minus big return differential. For example both in-sample and out-of-sample R-squared with smb as a predictand are about 3 times higher than the $\mathrm{R}$-squared in the regression where equally weighted returns are the predictand. This result is in accord with the effects that should be expected if the conjectured market timing mechanism is at play.

\section{Conclusion}

A behavioral story featuring investor sentiment and limits to arbitrage suggests that increases in the number of IPOs should predict subsequent decreases in stock returns, and that the effect should be concentrated among stocks that are difficult to value or arbitrage (e.g., small stock or high tech stocks).

I show that at monthly frequency, the number of IPOs predicts reliably equally weighted aggregate stock returns and predicts remarkably well the return differential between small and big firms, judged by both in-sample and out-of-sample criteria.

\section{References}

Amihud, Yakov and Clifford Hurvich, 2004. "Predictive Regressions: A Reduced-Bias Estimation Method," Journal of Financial and Quantitative Analysis, 39, pages 813-841.

Baker, Malcolm and Jeffrey Wurgler, 2007. "Investor Sentiment in the Stock Market," Journal of Economic Perspectives, Volume 21, Number 2, Spring, pages 129151.

Baker, Malcolm and Jeffrey Wurgler, 2006. "Investor Sentiment and the Cross-Section of Stock Returns," Journal of Finance, vol. 61(4), pages 1645-1680.

Baker, Malcolm and Jeffrey Wurgler, 2000."The Equity Share in New Issues and Aggregate Stock Returns,” Journal of Finance, vol. 55(5), pages 2219-2257,

mean of $s m b$ from the years that overlap with available data on number of IPOs is $100.21 \%$, and the standard deviation is $3.15 \%$. 
October.

Baker, Malcolm Ryan Taliaferro and Jeffrey Wurgler, 2006. "Predicting Returns with Managerial Decision Variables: Is There a Small-sample Bias?" Journal of Finance, 61, pages 1711-1730.

Campbell, John Y. and Samuel B. Thompson, 2006. "Predicting Excess Stock Returns Out of Sample: Can Anything Beat the Historical Average?," version dated November 10, 2006.

Clark, Todd E. and Kenneth D. West, 2007. "Approximately normal tests for equal predictive accuracy in nested models," Journal of Econometrics, Elsevier, vol. 127(1), pages 291-311, May.

Goyal, Amit and Ivo Welch, 2007. "A Comprehensive Look at The Empirical Performance of Equity Premium Prediction," Review of Financial Studies, Advance Access published on March 17, 2007.

Ibbotson, Roger G., Jody L. Sindelar and Jay R. Ritter 1994. "The Market's Problems with the Pricing of Initial Public Offerings," Journal of Applied Corporate Finance, pp. 66-74 Spring.

Mankiw, Gregory and Matthew Shapiro, 1986. "Do We Reject Too Often? Smallsample Properties of Tests of Rational Expectations Models," Economics Letters 20, pages 139-145.

Nelson, Charles and Myung Kim 1993. "Predictable Stock Returns: The Role of Smallsample Bias," Journal of Finance 48, pages 641-661.

Rapach, David E. and Mark E. Wohar, 2006. "In-sample vs. out-of-sample tests of stock return predictability in the context of data mining," Journal of Empirical Finance, Elsevier, vol. 13(2), pages 231-247, March.

Stambaugh, Robert F., 1986. "Bias in Regression with Lagged Stochastic Regressors," CRSP Working Paper No. 156, University of Chicago.

Stambaugh, Robert F., 1999. "Predictive Regression," Journal of Financial Economics, 54 , pages $375-421$. 